\title{
顎関節症治療の遠隔成績について
}

\author{
*小野尊睦・古川哲夫 ・大野睴八郎・山田重樹・福井正義・横矢 喬・島原政司 \\ **垣見庸三
}

\section{A post-treatment servey of temporomandibular arthrosis}

\author{
*Takatoki Ono, Tetsuo Furukawa, Kihachiro Ohno, Shigeki Yamada, \\ Masayoshi Fukui, Takashi Yokoya, Masashi Shimahara \\ **Yozo KaKIMI
}

\section{1. 緒言}

顎関節症は日常歯科臨床に扔いてしばしば経験される 疾患であるが，その病態生理，発生機序については不明 な点が多いため, 本症の診断は病歴, 現症, 諸種臨床検 査成績, さらに線所見などによっても困難なことが多い。 一方本症の治療法としては, 想定される病因の除去, 愁訴解消のため種々の方法が提唱され, 試みられている $か^{11,2)}$, 諸種の治療に反応の少ない難治性の症例の処置 に困ることもある.

私達も本症治療に当っては薬物療法, 靧運動制限, 運 動機能訓練，咬合調整などを主体とした治療を行なって いるが，治療効果の実態については不明な点が多かっ た. とくに治療期間中にまたは治療終了時に症状の改 善, 軽快があるにもかかわらず，その後再発をみる症 例，あるいは治療が長期間におよび治療が中断されて症 状が残る症例などについての追跡調査はあまり行なわれ ていない

そこで今回大阪医科大学口腔外科外来を訪ずれた顎関 節症患者の治療後の遠隔成績についてアンケート調査を 行ない, 発病から来院時までの期間, 主訴, 療法と予後 との関係について若干の知見を得たので報告する.

\section{2. 調查方法}

昭和 43 年 4 月から, 昭和 45 年 3 月までの 2 カ年の間 に大阪医科大学口腔外科外来を訪れた顎関節痛, 顎関節

* 大阪医科大学口腔外科学教空 (主任: 小野尊㓐教授)

Department of Oral Surgery, Osaka Medical College (Chief : Prof. Takatoki Ono)

受付 昭和 46 年 2 月 10 日

** 国立京都病院歯科（主任：垣見庸三博士）

Department of Dentistry, Kyoto National Hospital (Chief : Dr Yozo Kakimi)
雑音, 開口障害などを主訴とし，明らかな急性炎症々状 を欠く顎関節症の患者 56 例につき,アンケート調査を 行なった結果，41例の回答を得，それについて性別およ び年令分布, 部位, 性別と予後, 年令と子後, 発病から 来院日までの期間と予後, 来院時の主訴之予後, X線所 見と予後などの関係について調査を行なった。

\section{3. 調 查成 績}

\section{1. 症例内容}

（1）年令, 性, 部位別発生頻度（表 1)

41 例中, 男性 11 例, 女性 30 例で女性が圧倒的に多 く，年令的には 20 才代が最も多く，特に 20 才代の女性 が多く，打打よそ全体の $40 \%$ をしめていた。 また部位 に批いては, 片側性のものが 38 例で圧倒的に多く, 両 側性はわずか 3 例であり, 左右別では大差はなかった。

表 1 性別および年令分柯

\begin{tabular}{|c|c|c|c|c|c|c|c|}
\hline 性 年令 & $10 \sim 19$ & $20 \sim 29$ & $30 \sim 39$ & $40 \sim 49$ & $50 \sim 59$ & $60 \sim$ & 計 \\
\hline$q$ & 3 & 16 & 3 & 4 & 2 & 2 & 30 \\
\hline$\hat{\jmath}$ & 3 & 2 & 4 & 1 & 1 & 0 & 11 \\
\hline 計 & 6 & 18 & 7 & 5 & 3 & 2 & 41 \\
\hline
\end{tabular}

（2）発病から来院時までの期間（表 7)

発病から来院時までの期間では，1 カ月以内に来院し たものが 17 例でその内 2 週間以内に米院したものが 9 例であり，1 カ月以上たってから来院したものが 24 例 で,もっとも長いものでは 7 年というものがあった.

\section{（3）来院時の主訴（表 7)}

来院時の主訴としては, 疼痛あるい:喕関節雑音ある いは運動障害といらような単独でのものは少なく，多く の場合なんらかの形でそのいずれかを合欮しているよう であり，今回の調査に扮いては，そのもっとも苦痛とす るところのもの1つをとらえ主訴とした結果, 疼痛が最 
も多く 19 例で約半数をしめ, ついで関節雑音が 11 例, 運動障害が 10 例，その他が 1 例であった.

（4）治療法（表 7)

治療法としては薬物療法のみを行なったものが 22 例, 併用療法すなわち薬物療法と顎間固定あるいは咬合調整 を行なったもの 11 例, その他 8 例であった（その他の

表 2 性别と予後

\begin{tabular}{c|c|c}
\hline 性 & 症例数 & 症状の改善されたもの $(\%)$ \\
\hline$\delta$ & 11 & $7(63.6 \%)$ \\
$\uparrow$ & 30 & $14(46.7 \%)$
\end{tabular}

表 3 年令と予後

\begin{tabular}{|c|c|c|}
\hline 年 令 & 症例数 & 症状の改善されたもの \\
\hline 10才代 & 6 & 3 \\
\hline $20 "$ & 18 & 7 \\
\hline $30 "$ & 7 & 6 \\
\hline $40 "$ & 5 & 3 \\
\hline $50 "$ & 3 & 1 \\
\hline 60才以上 & 2 & 1 \\
\hline
\end{tabular}

表 4 発病から来院までの期間と予後

\begin{tabular}{c|c|c}
\hline 来院までの期間 & 症例数 & 症状の改善されたもの $\%$ \\
\hline 1 カ月以内 & 17 & $10(58.8 \%)$ \\
[2 週間以内 & 9 & $7(77.8 \%)]$ \\
1 カ月以上 & 24 & $11(45.8 \%)$
\end{tabular}

表 5 来院時の主訴と予後

\begin{tabular}{l|c|c}
\hline 主 訴 & 症例数 & 症状の改善されたもの (\%) \\
\hline 疼 痛 & 19 & $14(73.7 \%)$ \\
関節雄音 & 11 & $3(27.3 \%)$ \\
運動障害 & 10 & $4(40.0 \%)$ \\
その 他 & 1 & $0(0 \%)$
\end{tabular}

表 6 X線所見と予後

\begin{tabular}{|c|c|c|c|}
\hline & \multicolumn{2}{|c|}{ 症状の改善されたもの } & \multirow{2}{*}{$\begin{array}{l}\text { 症状の改善さ } \\
\text { れないもの }\end{array}$} \\
\hline & 急 速 & 徐 \& & \\
\hline $\begin{array}{l}\text { 関節腔の桩大の認 } \\
\text { められるす }\end{array}$ & 2 & 4 & 9 \\
\hline $\begin{array}{l}\text { 関節頭の位圆異常 } \\
\text { の認められるもの }\end{array}$ & 2 & 2 & 6 \\
\hline
\end{tabular}

表 7 症例内容の総括

\begin{tabular}{|c|c|c|c|c|c|c|c|c|c|c|c|}
\hline & 登病か & 5来院 & $\equiv$ & & & 訴 & 療 & & 法 & & 平均 \\
\hline & $\begin{array}{l}\text { 1力月 } \\
\text { 以内 }\end{array}$ & $\mid \begin{array}{l}1 \text { カ月 } \\
\text { 以上 }\end{array}$ & 疼痛 & 関篗篗 & 運動畫 & 他の & 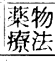 & 併用 & 弪 & & 学 \\
\hline $\begin{array}{l}\text { 急速に改善 } \\
\text { されたもの }\end{array}$ & 7 & 2 & 8 & 1 & 0 & 0 & 8 & 1 & 0 & & \\
\hline $\begin{array}{l}\text { 次第に改善 } \\
\text { されたもの }\end{array}$ & 3 & 9 & 6 & 2 & 4 & 0 & 6 & 5 & 1 & & \\
\hline $\begin{array}{l}\text { 改善されな } \\
\text { いす }\end{array}$ & 7 & 13 & 5 & 8 & 6 & 1 & 8 & 5 & 7 & & \\
\hline 症 例 数 & 17 & 24 & 19 & 11 & 10 & 1 & 22 & 11 & & & \\
\hline
\end{tabular}

ものとしては咬合調整のみのもの, 開口制限指導などが 含まれている).

\section{2. 頇関節症の予後}

（1）性別と予後の関係（表 2）

性別と予後の関係を調べた結果, 男性 11 例中症状の 改善されたもの 7 例 63.6\%, 女性 30 例中症状の改善さ れたもの 14 例 $46.7 \%$ で数字の上では男性の方が予後は 良好のようである。

（2）年令と予後の関係（表 3）

年令と予後の関係では, 20 才代では 18 例中症状の改 善されたもの 7 例であり. 他の年代層にくらべて症状の 改善のされ方は悪いようである.

（3）発病から来梡時までの期間之予後の関係(表 4) 発病から来院時までの期間と予後の関係では, 1 力月 以内に来院したものが 17 例で, 症状の改善されたもの が 10 例 $58.8 \%$ ，その内 2 週間以内に来院したもの 9 例 で症状の改善されたもの 7 例 $77.8 \% ， 1$ カ月以上たっ てから来院したものは 24 例で症状の改善されたものは 11 例 45.8\% であり, 症状発生から来院時までの期間か 短いほど症状の改善は良好のようである。

（4）来院時の主訴之予後の関係（表 5)

来院時の主訴と予後の関係では, 疼痛 19 例中, 症状 の改善されたもの 14 例 $73.7 \%$, 関節雑音 11 例中, 症 状の改善されたもの 3 例 $27.3 \%$ 運動障害 10 例中 4 例 $40.0 \%$ であり, 疼痛の治瘉率が良く, 反対に関節雑音, 運動障害は芳しくないようである.

（5）X線所見と予後の関係（表 6)

$\mathrm{X}$ 線所見と予後の関係では, 41 例中 27 例を選び観察 を行なった結果, なんら異常所見が認められなかったる の 2 例で, 閉口時関節腔の払大の認められたもの 15 例， 関節頭の位置異常の認められたもの10 例で, その治䉥 状沅は，関節腔の拡大の認められたもの 15 例中症状の 改善されたもの 6 例, 関節頭の位置異常の認められたも の 10 例中症状の改善されたもの 4 例で, 雨者の間には 差は認められなかった。

（6）発病から来院時までの期間と, 症状の改善のさ れ力について（表7）

発病から来院時までの期間と症状の改善のされ方につ いて調べた結果，急速に改羓されたもの，すなわち(治 療終了後 1 週間以内に改善されたもの（治療終了後 1 週 間以内としたのは最後の米院日に 1 週間分の投薬を行な い治療終了としたものがあるためである）9例あり，そ の内 1 力月以内に来院したもの 7 例であり， 1 力月以上 のものより多く, 次第に改善されたものでは反対に1カ 月以上たってから来院したものの方が多く, 症状発生か ら早く来院したものの方が早く症状が改善されるよらて ある.

（7）主訴と症状の改善のされ方について（表7） 主訴と症状の改善のされ方については，急速に改善さ 
れたものには主訴が疼痛であったものが圧倒的に多く, 次第に改善されたもの，改善されないものになるにした がって疼痛は少なくなり，反対に関節雑音拉よび運動障 害が多くなってくるようである.

（8）療法と症状の改善のされ方について（表 7 ) 療法と症状の改善のされ方については, 急速に改善さ れたものでは薬物療法のみのものが圧倒的に多く，次第 に改善されたものおよび改善されないものでは，薬物療 法のみでなく，併用療法も加わり，治療法も複雑化して くる傾向がある，ただし薬物療法単独の場合にも，䫇運 動制限, 強い咬合の禁止, 異常靧運動の自発的矯正など を指示しているので純粋に薬物療法とはいえないかもし れないが，顎間固定，徒手矯正などを除外したものを一 括して薬物療法とした.

（9）治療に要した日数と症状の改善のされ方につい $\tau$ (表 7 )

治療に要した日数は急速に改善されたものは平均 13.4 日間，次第に改善されたもの 33.6 日間，症状の改善さ れないもの 35.9 日間であり，急速に改善されたものは 治㞠日数も少なくてすむよらである.

\section{4. 考按}

従来買関節症の既往歴および現症さらに治療方法につ いての臨床統計的観察については比較的多く報告されて きたが3 6)，予後に関する臨床統計的観察はあまりみら れない.

今回 41 症例において行なったアンケート調査におい ての現症㧍よび既往歴についての臨床統計的成績は從来 報告されたものとは大差は認められず，年令分布におい ても20才代が最も多く，性別分布に拈いても女性が男 性にくらべて圧倒的に多いという結果を得ているが，こ れらについて論証する根拠となる資料は今回の調查では 得られなかった．顎関節症の年令的分布について，岡6) は内在性外傷で単関節性非炎症の買関節症は 10 才代後 半 〜20 才代に集中し，これは顎発育の終了期に一致す るため,この種の靧関節症の顎発育との間になんらかの 関連があるものと考えている，また男女差については， Freese, Scheman ${ }^{7)}$ のいう情緒的な因子が靧関節症に影 響をおよぼすことがあるとすれば，それが本症の男女差 の一因になっているとも考光られる，一方 Hankey ${ }^{4)}$ 女性では滑液膜は脂肪組織に富むため顎関節症に罹患し やすいと述べている.

性別と予後との関係において, 症状の改善されたもの は男性 $63.6 \%$ ，女性 $46.7 \%$ であるという結果を得てい るが，女性の率が低いのは特に20才代の女性において は 16 症例中, 症状の改善されたものはわずか 6 例 37.5 \%であるためであるが，これに対する説明はこの調査 からは得られなかった．特に20才代の女性においては 顎関節症に罹患する割合が多く，また治疮が困難である といら結果を得ている.
買関節症の主訴としては, 疼痛が最も多く, 順次関節 雑音, 運動障害となっており, 症状の改善は疼痛の症例 が最も良く，また主訴を疼痛とするものでは症状改善が 比較的短期間に行なわれている.このことは高田ら ${ }^{8)}$, 石井ら ${ }^{9}$ においても同様の結果を得ている. 一方治療法 之症状改善の関係では薬物療法単独のみの症例に症状改 善が短期間に行なわれたものが多い傾向があった. 薬物 療法のみの症例には主訴を疼痛とするものが多かったこ とを考え合わせると, 疼痛は雑音あるいは運動障害に比 較し, 日常生活において，より多くの苦痛となるため, 早期に来院して治療に専念するが, 雑音とか, 運動障害 は，日常生活に影響をおよほさない程度のものでは放置 されておることが多い。このため主訴を雑音, 運動障害 とする症例では, 症状がより悪化した後, 治療が行なわ れるため以上のような結果が得られたものと考えられ る. また顎関節症に拈ける買関節部の痛みは, 組織の器 質的障害だけでなく，単なる機能的障害によっても起 り，さらには精神的，情緒的因子も疼痛発生に関係する といわれているところから 。機能的，精神的影響によ るものでは比較的単純な治療法によって早期に症状改善 がみられるものと考えられる，これは本症患者に精神安 定剤の有効な症例が多いことや. Placebo でもある程度 の効果があったという中富ら ${ }^{10)}$ の報告からもらかがえる ところである。

発病から来院時までの期間と予後の関係では, 石井 $ら^{3)}$ によると，習慣性因子あるいは口腔内因子に起因す る新鮮例ではその予後はきわめて良好であり，反対に原 因不明のもの，陳旧性のもの，リウマチ因子を有する症 例では長期間の加療を要しながらも，その症状の反覆難 治例が多いといら結果を得ると述べているが，われわれ の調査においても同様に新鮮例では症状の改善のされ力 は良好であり，陳旧性のものでは症状の改善のされ方は 良くないようである。これは最初機能的あるいは単純な 器質的病変であった組織異常が症状発生から来院時まで の期間が長びくほど次第に固定化し，複雑化され，強度 の器質的変化も加わってくるためであろう.すなわち症 状の急速に改善されたものでは発病から来院までの期間 が 1 力月以内のものが多く，主訴のほとんどは疼痛であ り，薬物療法のみの症例が多かった。一方症状が次第に 改善された（2 週間以上）ものでは，来院までに 1 力月 以上も経過して, 疼痛以外に関節雑音, 運動障害のごと き器質病変を疑わせる症例が多く, 治療日数も 1 力月以 上となっていた。

今回の調査で注目されたことは, 平均治療日数 35.9 日の治療にもかかわらず症状改善のかんばしくない症例 が 41 例中 20 例あったことである.これらの症例に対し ては薬物療法を始めとし, 顎運動制限, 機能訓練, 咬合 調整など，諸種治療法が試みられたのであるが，症状改 善のみられないまま，治療が中断している，このことは 顎関節症の病因, 病態の多様性, しいては診断の囷難な 
ことから，適確な治療が行なわれていないことを示すも のであり, 顎関節の構造, 機能に関する局所的, および 全身的要因の解明と適確な治療法の確立の必要性が痛感 された.

\section{5. 結 論}

顎関節症治療の遠隔成續を検討するため，大阪医科大 学口腔外科外来を訪れ加療を受けた靧関節症の患者に対 し, 治療効果, 治療後の症状の有無, 種類などに関する アンケート調査を行ない，41例の回答を得，これを資料 として, 分析調査した結果次のような成績を得た。

\section{1 被検症例内容}

（1）靧関節症の罹患状況は，性別では女性（30 例） が男性（11 例）の約 3 倍をしめ, 年令では 20 才代 (18 例）が最も多く，左右別ではほとんど差は認められなか った.

（2）発病から来院時までの期間では 1 力月以内に来 院したもの 17 例，1カ月以上たってから来院したもの 24 例であった。

（3）主訴では疼痛が最も多く, 関節雑音, 運動障害 の順となっている.

（4）療法としては薬物療法のみのものが最も多く22 例であった.

\section{2. 顎関節症の予後}

（1）性別では男性 7例 $(63.6 \%$ ) の方が女性 14 例 (46.7\%) 上り症状の改善のされ方は良好であった。

（2）年令では 20 才代傼治性のものが多かった.

（3）発病から来院時までの期間では早期に来院した ものの方が症状の改善は良好であった。

（4）来院時の主訴のらち疼痛がもっとも改善されや すく, かつ短期間に改善されるものが多かった. 関節雑 音, 運動障害は改善が革いか, 改善さなないものが相当
数あった.

（5）薬物療法 22 例中 14 例, 併用療法 11 例中 6 例 に再発のない治㢈があり, とくに薬物療法のみでは治療 期間の短いものが多かった。この種の主訴には疼痛が多 かった。 一方併用療法では治療期間の長いものが多かっ た.

（6）X線所見亡予後の関係では，X線所見による予 後の判定は困難であった. た).

（本論文の要旨は第 15 回日本口腔外科学会総会にて発表し

\section{引用 文 献}

1) Schwartz, L., \& Chayes, C. M. : Facial Pain and Mandibular Dysfunction. Saunders Co., Philadelphia, London \& Toronto, 1968, p. 249 355.

2) Schwarty, L., 著, 河村洋二郎尌 : 腼関節異常. 医歯薬 出版, 東京, 1962, 201 283.

3）石井保雄, 他 : 䫇関節異常患者の臨床的钼察並びに考察. 口腔科学紀要 $6: 80 \sim 1141966$.

4) Hankey, G., T. : Temporomandibular Arthrosis. An Analysis of 150 Cases Brit Dent J $97: 249 \sim 270$ 1954.

5）中村允也：䫇閉節症の臨床的研究. 口病誌 $26: 986 \sim 1012$ 1959.

6）岡 達 : 顎関節症の研究, 成因および臨床像を中心に. 口科誌 $16: 116 \sim 1231967$.

7) Freese, A. S. \& Scheman, P. : Management of Temporomandibular Joint Problems. Mosby Co., St. Louis, 1962, p. 30 44.

8）石井保雄, 他：“顎関節症に対するミオブタゾリシン” の使用経験. 歯界展望 $30: 613 \sim 6171967$.

9）高田和彰, 他：“䫇関節症に対するミオブタゾリジン” の使用成績について. 口科誌 $18: 773 \sim 7791969$.

10）中富苾次郎, 他 : 罘関節症の臨床的研觉. 日ロ外誌 16 : 2231970. 